\title{
Publicity and domesticity
}

\section{Introduction}

From the activities that created modesty via the performance of wearing modest dress, we now move into the activities that created and maintained domesticity, the modest location in space and modest movement through space, as well as the public advertisement of such modest location and movement. The location of modesty par excellence was the domestic sphere, and the ideal Roman woman stayed at home. The following second-century epitaph sums up Roman feminine domesticity: "Here is buried Amymone wife of Marcus, best and most beautiful: She worked wool, was pious, modest [pudica], frugal, chaste and stayed at home." This sentiment was still in full force in the early fifth century as our evidence from Jerome, Augustine, and Pelagius will show. ${ }^{2}$ Staying at home, however, can mean many different things. The lifestyle of a Victorian middle-class wife and a north Indian Muslim bride living in the seclusion of a joint household may share an ideology of domesticity, but this may mean very different things to the two women - as the writings of British colonials make evident. ${ }^{3}$ Did the Roman woman live exclusively within the walls of her house and even there in quarters separate from men as upper-class Greek women were supposed to do? Not according to Roman writers like Plutarch who marked the difference between the lifestyles of Greek and Roman women as one of those things that defined romanitas in opposition to Hellenistic ways. ${ }^{4}$ According

\footnotetext{
"Hic sita est Amymone Marci optima et pulcherrima, lanifica pia pudica frugi casta domiseda." CE 237 in: Lattimore 1942: 295.

2 Also, not surprisingly, in late ancient funerary epitaphs. Trout 2013: 20-2.

3 For examples see de Souza 2004.

4 See Plutarch's "Bravery of Women," in Moralia 242.e-f: "I do not hold the same opinion as Thucydides. For he declares that the best woman is she about whom there is the least talk among persons outside regarding either censure or commendation, feeling that the name of the good woman, like her person, ought to be shut up indoors and never go out. But to my mind Gorgias appears to display better taste in advising that not the form but the fame of a woman should be known to many." Babbitt I931: 475.
} 
to Plutarch, the heroism of Roman women outside the house was a proper subject for praise. Likewise, a matron appeared at dinner parties with her husband, virgins participated in religious choral groups and athletic competitions, and women of all ages participated in commerce as both buyers and sellers. ${ }^{5}$ Roman women did not stay at home all of the time.

The domesticity of women was an ideal, overlapping with the other qualities of a good woman, such as chastity, modesty, and piety. It was valued in itself and for its contribution to the overall modest reputation of a woman and, by extension, her household. A woman's sexual integrity and modest conduct, including domesticity, were crucial to the public, political image of her family. Attacking a household by questioning or slandering the virtue of its women was a time-honored tradition in Roman historiography, forensic rhetoric, and satire. The lurid accounts of women's immodest and lustful private lives were a mainstay of invective against unpopular emperors into the fifth and sixth centuries. ${ }^{6}$ Just as the details of inappropriate behavior were part of attacks on households, so were the details of chaste feminine virtue part of a family's reputation-building capital. Kate Cooper describes the situation of the upper-class Roman family in a chapter aptly titled "Private Lives, Public Meanings":

If a man's enemies were bent on discerning in his private life an intemperance that could compromise the fulfillment of public duty, it was his task to undermine the plausibility of such revelations by a deft broadcasting of his probity. This meant that he should make as public as possible his solemn affection for the chaste women of his family. Paradoxically, the modesty of his wife and female relatives was of use to him only if it was widely acknowledged. ${ }^{7}$

Staying at home, then, was not a non-action any more than being covered up was a non-action. Domesticity was not incarceration or strict seclusion. It was as much about how one was perceived in relation to domestic and public space as it was about where one actually was at any given moment.

This chapter begins with a look at Roman women's domesticity as it was publicized in funerary epigraphy and visual representations. We then move to the interior of the domus as described in Jerome and Pelagius. The next section explores the negotiation of gendered spaces, women's seclusion, and ideal domesticity in ethnographic examples. Finally we leave the

\footnotetext{
G. Clark 1993 .

${ }^{6}$ For a notorious example see Procopius The Secret History, trans. Williamson I98I; also Richlin 1992.

7 Cooper 1996: 13.
} 
house again and look at the creation of domestic personae while on trips outside the domestic space by examining the importance of the women's entourage in Augustine and our other ancient Christian authors. While moving from graveyards outside the city walls to the interiors of Roman homes to the curtains of South Asian seclusion to the difficult journey from home to church, we are considering domestic women's agency in creating their reputations for 'being at home.'

\section{Departed women, at home outside the city}

We will first enter into the world of Roman domesticity and publicity by way of funerary sculpture and epigraphy. Our aim is to expand our notions of the public and the private and how these were created in the Roman world. We are looking both at specific spaces and objects and at the work they did to stabilize and naturalize boundaries. These boundaries were not rigid physically or conceptually but were socially constructed and in constant flux. The move is not from single examples to general precept. Rather, I try to take a few examples of epitaphs and funerary portraits and explore their workings, keeping in mind that a single object or phenomenon may have played very different roles over time or depending on which group of people interacted with it.

Jas Elsner claims that art history always faces a methodological dilemma: it examines very specific objects but then generalizes from them, always positing more than the objects can feasibly prove by themselves. ${ }^{8}$ This is the dilemma, perhaps, of all history and certainly of ancient history, which must constantly fill in the gaps by comparison or by over-interpretation of the sources. Both comparanda and sources are given as evidence for cases they cannot definitively prove. The very specificity, the realness, of the evidence stands in, by sleight of hand, for authentic proof of very general claims. Elsner suggests that closer attention be paid to the rhetorical function of close analysis. In the case of this book, the description of material evidence - that of clothing in the previous chapter and of funerary inscriptions and statuary in this chapter - does not function as positive proof for the points I wish to make about the modest self-representation of the Anician women. My description of these objects functions, rather, as an entry point for the historical imagination.

\footnotetext{
${ }^{8}$ Elsner 2006. I am also indebted to Dr. Elsner for his comments on April 25, 2008, during the seminar "On Ekphrasis in Art History," which was given as part of the 2008 Mellon Dissertation Seminar at Emory University: "Critical Engagement, Community and Subjects of Art History."
} 
One way in which a family could publicize the domestic virtue of its women was with inscriptions, portraits, and other artistic representations on funerary monuments. From the most elaborate poetic eulogies to the simplest catalogues of virtue, the most common presentation of women was that of the chaste and beloved matron. At death, the woman of domestic virtue left home and even the city, but not the household. Since Romans considered human remains (either ashes or corpses in sarcophagi) polluting, burial grounds were outside the city walls, often along the major roads into and out of the city. ${ }^{9}$ A woman's domestic reputation, ideally built up over a long and fertile life, here joined the political and military successes of the men who predeceased her. The matron's reputation for chaste domesticity also joined the piety of freedmen and freedwomen, the sweetness of lost children and youths, the musical, medicinal, and artisanal skills of professionals and slaves. ${ }^{\text {IO }}$ While almost all Roman burial sites produce more evidence for male decedents than female, ${ }^{\text {II }}$ the greater part of biographical detail and especially description of character falls to that of women. Richmond Lattimore summarizes the tone of epitaphs in the Imperial and later Roman periods:

What we are presented with first and last is the picture of an ideally happy family; devoted husbands and wives, affectionate parents and obedient children, even kind masters and grateful slaves and freedmen. The virtues, especially those which go to make up a family, are magnified; we have, not precise reminiscence, but the elaboration and adaptation of an ideal. It follows from the centralization of power under the empire that in this period the ideal more than ever concerns the family, not the state; and from this it follows in turn that women play the predominant part they do ... the virtues we find holding always the highest place are the old-fashioned domestic virtues of women. ${ }^{\mathrm{I}}$

The increasing importance of domestic virtue or the domestic ideal in Imperial Rome has attracted the notice of other scholars, such as Cooper, although they have revised his explanation for the shift. ${ }^{13}$ Lattimore's observation emphasizes the funerary idealizations in epitaphs by which

\footnotetext{
9 Toynbee 1971, 1996.

ro Lattimore I942. The particular virtues of all members of a household, free male citizens, matrons, children, freedmen, clients, slaves, and other dependants worked together. Monuments were dedicated for slaves or clients by masters and vice versa.

II Arnold 2007. Christian burial evidence from the late Roman period is a notable exception. Trout 20I3:I4-I5.

12 Lattimore 1942: 299-300. For a somewhat unsympathetic analysis of these developments see Thébert 1987.

13 Cooper 1996.
} 
a woman's modesty could become widely known and which was increasingly popular through the Imperial period. The funerary epitaph and portrait assimilated the deceased to the ideal, and the more piety a family showed in the semi-public space of the burial plot, the more the virtue of ancestors, female as well as male, attached to the living household. Roman families visited their dead on set days after burial, on the decedents' birth and death anniversaries, and at festivals for the dead such as the dies Parentales, the Lemuria, and the Rosaria. ${ }^{14}$ These visitations to the family burial places included the offering of flowers, notably violets and roses, to the dead, but most importantly they were the occasions for funerary meals shared among the living and the dead of both sexes. Long metal tubes into the sarcophagi often served as access points to human remains so that the funerary meals could be shared more directly with the deceased. Placating the spirits of the dead was an important function of the meals, but the meals also served as an opportunity for a household to display allegiance to and descent from virtuous forebears. While Christian authors insisted that Christian burial and mourning practices should differ from non-Christian practices, there were no fixed Christian burial liturgies in the late Roman period and the bulk of evidence suggests that burial and memorial practices remained, for the most part, family affairs, not church business. ${ }^{15}$ The dead were models for the living household, guarantors of its legitimacy, ${ }^{16}$ and advertisers of domesticity. Epitaphs could generalize the domestic virtues of a woman into an ideal that the living both benefited from and worked to emulate. Any praise for the living - or the dead - in Latin literature began with the virtues of his/her ancestors. ${ }^{17}$ It was therefore necessary to ensure that one's ancestors were known, and known to have been virtuous. A person's reputation was not his or hers alone, but extended throughout the family, past and present.

The majority of examples from Roman funerary statuary and epigraphy are conventional descriptions of the deceased. This is part of their

${ }^{14}$ The dies Parentales were the official commemorations of the dead from I3 to 2I February. The Lemuria were rites conducted on May 9, II, and 13 to guard against ghosts and the hungry dead. Roses and violets were always common offerings to the dead but especially during the Rosaria in May-June. Toynbee 1971, 1996.

is Rebillard 2009: I59-60.

16 The wife who has spent her entire life, from her youthful virginity, with one man is very common in funerary inscription. Also, inscriptions mention the similarity of a woman's children to her husband and her satisfaction with one man or her 'ignorance' of strangers. Lattimore 1942.

${ }^{17}$ Jerome, Pelagius, and Augustine all play on the theme of nobility of ancestors in their letters to the Anician women. In essence, all pay appropriate homage to the Anicii family but suggest that Demetrias outdoes her consular forefathers by giving up nobility and worldly honors. For this theme in the letters to Demetrias see Jacobs 2000. 
value, for they can convincingly demonstrate a long-standing tradition for the idealized domestic woman in Roman society. They include catalogues of feminine virtue that employ a very limited vocabulary for praise and include a number of formulae. "Chaste, modest, decent, wise, generous, praiseworthy" reads one epitaph.$^{18}$ This covers most of the feminine virtues. Others include frugality, piety, obedience, simplicity, sweetness, beauty, gravity, dignity, old-fashioned chastity, and attention to domestic duties, especially woolworking. One epitaph reads, "Her wool was never out of her hands without good reason"; another notes a woman's contentment with her domestic sphere, "This woman was satisfied to live with her good husband, she desired nothing more than to rejoice in her household." ${ }^{\text {I9 }}$

The visual representations, both portraits and other images that accompany women's funerary monuments, tend also to show women as chaste, dignified, and domestic. Conventional images such as mirrors, spindles, combs, and cosmetics boxes signal the gender of the deceased in less elaborate memorials. The funerary evidence shows that the moralizing discourse against women's beautification and love of clothing that we explored in the last chapter had its counterweight in associations between women's adornment and chaste sexuality. Since men's and professional women's tombs tended to carry the emblems of their work such as lyres, anvils, medical implements, craft tools of all kinds, the presence of beautification 'tools' seems to point to attraction as part of women's work or duty (labor, officium) mentioned so often in epitaphs. ${ }^{20}$ While these images can have religious meanings and sometimes appear on male memorials as well, they usually represent the domestic work of women, textile production and reproduction. The emphasis on the arts of beauty suggests the erotic role of the matron. Portraits, which were often mass-produced with the features of the deceased only added after purchase, showed dignified women. Their hair is elaborately arranged, often in the style of the current imperial women. ${ }^{2 r}$ Some women wear veils and hold them with one hand in a gesture of modesty (the pudicitia type). ${ }^{22}$ Both hair and veils suggest

${ }^{18}$ CE 843. Lattimore 1942: 295.

19 CE 1988, I4; CE I66. Lattimore 1942: 297.

20 da Costa 1997.

${ }_{21}^{21}$ The interest in Roman women's hairstyles for many years was confined to an interest in dating statuary. Since imperial women had unique and easily identifiable hairstyles and the populace copied these precisely (at least in statuary), an entire dating system can be based on coiffure. Kleiner I992: 8-9.

22 Kleiner 1992: 40-I. 
the good order and chaste reputation of the woman. Only girls and very old women are shown with simple hair-dos; women with loose hair were in mourning or in the guise of mythological persons. ${ }^{23}$ The composition most indicative of a woman's domestic role was the husband-wife portrait in which the couple's right hands are joined. ${ }^{24}$ These concordia portraits emphasize the domestic fidelity of the couple and the orderliness and harmony of the household.

The danger of conventional forms, whether in art or literary sources, is that they seem to lack authenticity. If modest, domestic representations of women were simply a funerary convention, how can they prove anything about broad cultural understandings or the self-understandings of Roman women? Yet Roman antiquity highly valued tradition and the conventional; originality was rarely a cause for praise. Whether the ideal ever was achieved, or even could be, its material presence acted on the community and on individuals. Kampen argues that the historian of gender should understand material representations not merely as reflections or illustrations of gender norms but as part of the means by which gender is created.

Representation, the interpretation of the visual world through material means, does a number of things essential to the construction of gender. Among other things, it shows people idealized forms of themselves, forms by which to recognize the categories to which their society assigns them and by which to mark their hopes and desires. It also shows people how they differ from one another both as individuals and as members of categories (for example, of status or of age). ${ }^{25}$

The gendered subject and the material and literary creations of her culture develop mutually rather than one being the product of the other in any straightforward way. Men and women represent themselves as a commentary on or iteration of the tradition. They must live lives in relationship to their own ideals and those surrounding them.

Although conventional forms and language give a useful entrée into the public domesticity of Roman women, the following examples initially seem out of place. The first is an epigraph written for a concubine as if she were a matron; the second is a group of funerary portraits of matrons in the guise of a nude Venus. These funerary representations would seem to go against the grain. Close reading of the aberration, however, can generate a richer understanding of the convention.

${ }^{23}$ For untying hair as a gesture of women's mourning see Corbeill 2004: ch. 3.

${ }^{24}$ Kleiner 1992: 79-80. ${ }^{25}$ Kampen 1996: 17. 
Below is the middle section of a long poem in praise of the freedwoman Allia Potestas, dedicated by her lover and former owner. The first part extols her character, the second her physical charms.

She was strong, good, resolute, honest, a most reliable guardian, neat at home and neat enough abroad, well known to everybody, and the only person who could rise to all occasions. She spoke little and was never rebuked (for speaking at the wrong time); she was always first out of bed, and the last to go to bed and rest, and she went only after her things were put away in proper order. Her yarn was never out of her hands without good reason. No one excelled her in obedience and good habits.

She was of fair complexion, with lovely eyes and gold hair. Her face always had an ivory pallor such as they say no mortal ever had. On her snow-white bosom the shape of her breasts was slight. Her legs? Atalanta's figure would be comic beside her. She was never sparing, but lovely as she was, she was generous with her body. She kept her limbs smooth, and every hair was looked for (and removed). ${ }^{26}$

The first part is entirely in keeping with the catalogues of virtue for a Roman matron. She is noticeably domestic. Her care and concern for the home are extraordinary and, while one might wonder when she had time to go out, she is well known (notissima) by the people. Lattimore finds that the "poem is completely sincere, guaranteed as spontaneous by its very defects." 27 Lattimore is convinced that the "portrait of a lady, cultured, quiet, domestic, and hardworking" is rendered absurd by the "embarrassing detail" of the erotic description. ${ }^{28}$ Surely her domestic goodness is betrayed by the public display of her pale, naked body, kept pale by staying indoors and properly covering herself on outings? Either the "infatuated patron" is making up her chaste, matronly character entirely and adding it as a ridiculous mask for his deceased lover or he is badly mistreating a domestic paragon by revealing her not merely in the privacy of her home but in the intimacy of the bedroom.

This poem, however, with its odd juxtaposition tells us something about the nature of public and private, domestic and erotic in the Roman

\footnotetext{
${ }^{26}$ The translation is Lattimore's; see his notes $274,277,278$ for problems of interpretation and translation. Lattimore 1942: 298-9: "fortis sancta tenax insons fidissima custos / munda domi sat munda foras notissima volgo / sola erat ut posset factis occurrere cunctis / exiguo sermone inreprehensa manebat / prima toro delapsa fuit eadem ultima lecto / se tulit ad quietem positis ex ordine rebus / lana cui e manibus nuncquam sine caussa recessit / opsequioque prior nulla moresque salubres / haec sibi non placuit numquam sibi libera visa / candida luminibus pulchris aurata capillis / et nitor in facie permansit eburneus illae / qualem mortalem nullam habuisse ferunt / pectore et in niveo brevis illi forma papillae / quid crura Atalantes status illi comicus ipse / anxia non mansit sed corpore pulchra benigno / levia membra tulit pilus illi quaesitus ubique." CIL vi 37965.

${ }^{27}$ Lattimore 1942: 298. ${ }^{28}$ Lattimore 1942: 298.
} 
world. It also adds to our understanding of what counted towards the creation of a household reputation. Although the dichotomy of public and private was important to the Roman worldview, the two hardly functioned as they do today. Other than celebrities and politicians, few people today spend a great deal of time or energy fashioning a public image of their private lives in order to secure professional advantage. We have resumés and credentials, yearly reviews, and letters of recommendation that are not likely to mention domestic concord, sexual restraint, or modest demeanor. Our habits at home are, in theory at least, irrelevant to our career advancement. Neither do we often conduct interviews in the living-room or confer with our top executives in the bedroom. The Roman home, however, was as much a place of business, manufacture, and politicking as of familial intimacy. ${ }^{29}$ The Roman world explicitly associated domestic and civic reputation and the actual spaces for civic and domestic life overlapped in ways they perhaps no longer do, at least in the imaginative ideal. The erotic aspect of the poem strikes Lattimore as being in very poor taste. It wants to show the union of goodness and beauty in the common ideal but misses the mark by giving the realia of domestic chores and erotic preparation. The very realness of the description of Allia Potestas, in Lattimore's words, "the matchless garrulity and lack of tact of the author," distracts the contemporary reader from the importance of the domestic and erotic in the Roman public sphere. A man's sexual faults, his women's indiscretions, were cause for public and graphic attack. But a woman's desirability and availability to her husband while she properly stayed at home guaranteed offspring and survival of the family as a whole. Allia Potestas' sexuality is divinized and if the mundane details of depilation render it more concrete, so much the better for her patron's reputation. The woman's sexuality, divinized, cared for, and made available to her patron was nothing to hide. She could not officially have the status of a matron but her sexual devotion to her patron ought not be in doubt. The Roman sensibility did not shy away from the fact that a woman, however ideally modest and domestic, was and should be sexually active with her husband. The household depended on it.

Moving from the realm of epigraphy to that of funerary portraits, we find, once again, the incongruous spectacle of a nude matron. To the contemporary eye, nothing could appear less domestic and retiring. However,

29 See essays in Laurence and Wallace-Hadrill 1997. Kate Cooper gives a re-evaluation of public and private in Roman homes and concentrates on the power of the paterfamilias to manage scrutiny of the domestic sphere in Cooper 2007b. For the idea of the 'atrium turned forum' in the late antique period see Thébert 1987. 
in the first and second centuries, wealthy persons, often imperial freedmen, began to decorate their sarcophagi and burial complexes with portraits of the deceased in the guise of gods and heroes. One set of statues consists of female nudes standing contraposto with the right arm raised across the breasts and the left hand held in front of the pubis. The statues are copies of canonical Venuses, and symbols of Venus such as the dolphin accompany the nudes at the base. The heads, however, are not youthful renderings of the deceased at a 'godlike' moment of beauty. They are instead portraits in the tradition of severe and 'realistic' likenesses in which the viewer sees the moral seriousness of the deceased in the firm lips, lined skin, and forthright gaze. ${ }^{30}$ The hairstyles are high and elaborate, possibly wigs. Eve D’Ambra, following Larissa Bonfante, calls the nudity a 'costume,' but both the heads and bodies of these statues, no matter how incongruous they may seem, are representations of an ideal. Like Allia Potestas, these matrons represent virtuous character and sexual intimacy, both of which are ideally kept within the home, in a public space where they can testify, equally, to the legitimacy and continuity of the family and its reputation. The matrons take the 'costume' of both divine sexuality and exceptional virtue out of the home and into the world. A living matron surely could not appear naked before a general audience, but general knowledge of her sexual attachment to her husband, manifest in children who resembled him, was as important as general knowledge of her virtues, manifest in her woolwork or housekeeping.

\section{The ladies are at home}

This tour of funerary monuments outside the city gates gives a sense of the complexities of women's ideal domesticity. The Roman upper-class woman, or woman who aspired to upper-class notions of morality, should be constantly working at home, but well known about the city. Her sexuality should remain within the bounds of the household, but the success of her sexuality should be widely evident in her childbearing and the likeness of her children to their father. Although she was a dedicated virgin and not a matron, Demetrias' advisors expected a domesticity of her that was similarly complex. As the heiress of a vastly wealthy and noble family, Demetrias was automatically a public figure. She opened herself to even greater public scrutiny by taking up an unusual lifestyle. Pelagius exhorts

\footnotetext{
30 D’Ambra 1996.
} 
her to remember, as she embarks on her career as a dedicated virgin, that her life is a spectacle that the entire world is watching.

Many are held in suspense by these beginnings, many by the sweet odor of your fame. All long to hear I know not what wonderful thing about you. And those acquainted with the quality of your journey's commencement now look forward to the quality of your future conduct [conversationis]. Suppose that all faces and eyes are together turned toward you and the whole world has sat down together for the spectacle of your life. Beware, lest through you, such a number of souls be scandalized. Let them not find in you less than they require. But truly, why do I go on with you about human spectators and draw encouragement for you from their expectations? God Himself, Lord and ruler of all, with all the army of angels, watches your struggle. There he prepares the crown of immortality for you who are battling against the devil, and he makes heaven's reward an incitement to victory. See what spirit and what strength you ought to bring forth for such a display and recognize from the dignity of the spectators the importance the struggle deserves. ${ }^{3 \mathrm{I}}$

This passage places the everyday behavior of Demetrias (conversatio) in a performative and agonist context. Like the martyrs who simultaneously entertained the crowd and did public battle against the devil, Demetrias must play to both a human and a divine audience. Pelagius encourages her to become a spectator of her own life from the point of view of the extended Christian community, who look to her for inspiration and a model of virtue, and from the point of view of God and the angels who prepare and who will distribute her victory crown. In this drama, Pelagius plays the part of fan, much like Jerome in the opening lines of his missive to Demetrias. ${ }^{32}$ While the contest metaphor for Christian living went back to Paul, we should not consider this arena that Pelagius builds in Demetrias' mind an empty literary convention. The public entertainments including theater, gladiatorial contest, and horse racing were as popular in the Roman world of the early fifth century as they ever had been. ${ }^{33}$ Even a sheltered young girl in the late Roman world would possess the cultural

${ }^{31}$ Pelagius, Demetr. I4.3: "Multum his initiis, multum famae tuae odore suspensi, omnes mirum de te nescio quid audire desiderant. Et qui profectionis tuae cognovere virtutem: nunc conversationis exspectant. In te nunc puta cunctorum ora oculosque conversos, et ad spectaculum vitae tuae totum consedisse mundum. Cave, ne per te tantorum animi offendantur: nec minus in te inveniant quam requirunt. Verum quid ego tecum de hominibus ago, eorumque de te expectationem ad cohortationem tuam traho? Deus ipse omnium rector ac Dominus, cum omni angelorum militia certamen tuum spectat: ibi contra diabolum dimicanti parat aeternitatis coronam, et coeleste praemium incitamentum victoriae facit. Huic tanto spectaculo vide quem animum, quam debeas efferre virtutem: et certaminis magnitudinem de spectantium dignitate metire." PL 30.29B-29C.

32 Jerome, ep. I30.2, CSEL 54.

33 Leyerle 200I. On pantomime and its spectators in the eastern empire see Webb 2009. 
competence to envision the roaring crowds and competitive display of the contest. Pelagius frames Demetrias' quotidian behavior in terms of a staged combat performance. This indicates that her everday conduct was a matter of self-conscious display before an audience who recognized that they were watching a display and who were competent to judge the quality of that display.

Despite the care that Demetrias must take to impress her viewers, human and divine, Pelagius insists that she spend as little time as possible in the public view. After exhorting her to transfer her nobility of family to a nobility of soul, he advises her to limit both her visits outside the home and her reception of visitors. The passage draws attention to the double necessity for the reputable women to both stay at home and be seen to stay at home.

I judge it unnecessary to warn you that the number of occasions for going out in public should be few, since worldly good breeding has also taught you this from your childhood, and you readily understand that you must protect it much more in this life, which seclusion best befits. This, I do advise you, that you place a most firm limit to the formal visits which need to be made to you in your own room [in cubiculo tuo]. Let them not be too often, or daily, or else they will appear to produce disturbance rather than the accomplishment of a duty. ${ }^{34}$

This is not advice to cut off all contact with the outside world. Demetrias must go out at some times and she must receive visitors. Her social class, which he has just emphasized, demands both, even if it has been considerably spiritualized. Instead of suggesting that public outings and the formal reception of clients and peers are no longer necessary, her would-be mentor suggests a program of limitations. The question is not so much whether she will appear in public - a public that could be located outside the home or in her innermost chamber (cubiculum) - but how she will manage and frame her public self so as to maintain a reputation of domesticity. If anything, the rarity of public outings and formal visiting hours (salutatio) might heighten the effect. The well-timed self-presentation of the noble girl to her clients and peers in the intimate space of the inner chamber would underline her general and unusual hiddenness. Whereas

34 Pelagius-Haer, Demetr. 22.2: "Superfluum arbitror te monere, quam parca in procendendo debeas esse, quam rara: cum te hoc etiam saecularis ab infantia honestas docuerit, et facile intelligas id tibi multo magis in hac vita esse servandum, quam maxime secretum decet. Illud admoneo, ut ipsis quoque salutationibus, quae tibi in cubiculo tuo exhibendae sunt, certissimum modum ponas: non sint nimiae, neque quotidianae, ne non tam officium, quam inquietudinem praestare videantur." PL 30.37. 
nobility and reputation (honestas) and the duty associated with her social position (officium) previously motivated Demetrias' performances of domesticity, now the life of consecrated virginity motivates more striking performances.

According to Pelagius, who asks for visibly superlative conduct in a virgin, ${ }^{35}$ the noblewoman dedicated to Christ must outdo the ordinary noblewoman in her womanly virtue. Her domesticity must also be superlative. Domesticity, however, is a state that is created by the careful negotiation of boundaries, as we saw earlier in the funerary evidence. Demetrias is not self-incarcerated like some of her contemporaries who depended on second-hand reporting for publicity. ${ }^{36}$ Choosing her outings, their manner, and their motivation was as important as keeping them sparing and infrequent (parca, rara). Setting a limit on the public access to her bedchamber constituted part of the interpretive framework of those occasions for her visitors. Domesticity was being created even as Demetrias greeted her public.

Immediately following his advice on outings and visitors, Pelagius recommends the time, place and manner of Demetrias' prayer and scriptural study. "Pray for these hours each day in a more secluded part of the house, with the door of your chamber closed. Make use of solitude for yourself even in the city, and, removed from people for a brief time, join closer to God." The privacy of the inner chamber is not enough, however, to cement the reality of Demetrias as a woman who can be rightly praised as domiseda. The sentence continues, "and when you return to the presence of your family, display the fruits of your reading and prayer." ${ }^{37}$ Even this privacy within the privacy of the home requires the audience of Demetrias' mother, grandmother, and extended household for validation. Like the matron who is properly out of view in the inner chamber, the fruits of her appropriate intercourse with her husband in that chamber must be made public through the advertisement of children "ressembling

35 Pelagius-Haer., Demetr. I7.A "Let the holiness of the virgin shine forth to all like the brightest star, and let her reveal the greatness of her future reward through the unique way she conducts her life." "Resplendeat omnibus clarissimi in modum sideris sanctitas virginis: et futuri praemii magnitudinem, de novitate conversationis ostendat." PL 30.0033.

${ }_{36}$ The stories of desert asceticism from Egypt were very popular in Rome. Palladius reports the visit of the pious Roman lady Melania the Elder who traveled to Egypt to make a tour of famous ascetics and who visits a woman named Alexandra who has immured herself in a tomb. They speak through a window in the tomb. In Meyer 1964: 36-7.

37 Pelagius-Haer., Demetr. 22.23: "His tu per singulos dies horis in secretioris domus parte ora, clauso cubiculo tuo. Adhibe tibi etiam in urbe solitudinem, et remota paulisper ab hominibus, proprius Deo jungere: aspectuique tuorum reddita, lectionis fructum et orationis ostende." PL $30.0037 \mathrm{~B}$. 
their father." Demetrias, the bride of Christ, must also make public the fruits of her intercouse with divine scripture in the privacy of the inner chamber.

Jerome gives his advice for the virgin's domesticity and the regulation of public outings in two separate passages. He gives similar advice to that of Pelagius for time spent in solitary prayer and study. He then tells Demetrias that she must never be without wool in hand. This piece of advice moves her from activities of the cubiculum to those of the atrium. These, traditionally, were the spaces for women's two main domestic duties - reproduction and production. ${ }^{8} \mathrm{He}$ does not specify the exact spaces for prayer, reading, and woolworking. The latter, however, is clearly a group activity while the former two are not. Reading scripture is also associated with delectatio, enjoyment, which suggests the intimacy of the cubiculum. Here is Jerome's daily routine for Demetrias:

As well as the rule of psalms and prayers which it is always necessary for you to perform at terce, sext, none, in the evening, at midnight, and in the morning, decide which hours you should learn holy scripture by heart, how much time to read, not as a burden but for the delight and instruction of your soul. And when you have finished this interval, and care for your soul has often stirred you to fall to your knees, have wool always in your hands, either draw the strands of thread down with your thumb, or let the spindles be turned in the baskets for weft-threads to be twisted and collect the thread of the other women into a ball or set them up for weaving. Inspect what is woven, reprove what is defective, and determine what still needs to be done. If you are occupied with such various labors, the days will never be long for you; rather, however the summer sun lengthens them, the days on which some work is set aside will seem brief to you. By following this advice, you will save both yourself and other women and you will be an instructress of holy conduct [magistra sanctae conversationis], and the chastity of many women will be to your credit. ${ }^{39}$

${ }^{38}$ For the role of the cubiculum in Roman Christian thought see Sessa 2007.

39 Jerome, ep. I30.15: "praeter psalmorum et orationis ordinem, quod tibi hora tertia, sexta, nona, ad vesperum, medio noctis, et mane semper est exercendum, statue, quot horis sanctam scripturam ediscere debeas, quanto tempore legere, non ad laborem, sed ad delectationem et instructionem animae. cumque haec finieris spatia, et frequenter te ad figenda genua, sollicitudo animae suscitauerit, habeto lanam semper in manibus vel staminis pollice fila deducito, vel ad torquenda subtemina in alueolis fusa uertantur aliarumque neta aut in globum collige aut texenda conpone. quae texta sunt, perspice; quae errata, reprehende: quae facienda, constitue. si tantis operum uarietatibus fueris occupata, nunquam tibi dies longi erunt, sed, quamuis aestiuis tendantur solibus, breues uidebuntur, in quibus aliquid operis praetermissum est. haec observans, et te ipsam saluabis et alias et eris magistra sanctae conversationis, multarumque castitatem lucrum tuum facies." CSEL 56. I owe many thanks to anonymous reviewer B from Cambridge University Press for his/her comments on this passage and its translation. Some of the tangle, doubtless, is due to Jerome's hazy understanding of the technical aspects of spinning and weaving. 
Demetrias must have time for intimate study of scripture, which he describes in overtly sexual language in his earlier letter to Eustochium, ${ }^{40}$ a letter that he references in his work to Demeterias and assumes she can access. $^{4 \mathrm{I}}$ This intimate study, however, is framed by activity among other women in more public domestic settings. The order of psalmody and prayer are for communal practice, and Jerome imagines textile work as similarly communal. Jerome moves from activity to activity, each associated with a particular space, the cubiculum (or some other private space) and the atrium. Domestic woolworking should, according to custom, be on display to visitors.

Wool work and weaving were, thus, part of the traditional household duties of married Roman women. By tradition female work, including that related to textiles, was primarily to take place in a domestic setting. However, spinning and weaving were to be done not in seclusion but in the most public space of the Roman house, the atrium. This was the traditional location of the loom, and the housewife's work by the loom should likewise be exposed to visitors. ${ }^{42}$

Roman literary evidence so embedded these in social usage that no other spaces could be imagined for these activities. Lucretia, the virtuous married Roman woman par excellence, is spinning in the atrium late into the night when the men check in on their wives. ${ }^{43}$

Archeologists, however, show that the daily use of these seemingly well-defined spaces was far more diverse than the rhetoric of space would suggest. While the atrium was the public reception space, par excellence, of the Roman paterfamilias and domestic production space for the materfamilias, ${ }^{44}$ it was also a space for domestic production, everyday storage, and casual meetings. At night, it could, like any other room, be the bedroom of servants or slaves. Likewise, the cubiculum, which was ideally the space of secrecy, private interviews, sexual activity, and literary production, was a multi-use room that served any number of purposes throughout the day and over longer periods of time. Few seem to have been set aside as permanent 'bedrooms' in the contemporary Western sense..$^{45}$ Household space did not, in fact, simply provide appropriate settings for particular gendered activities.

'Women's space,'46 and domestic space in general, was largely defined by the persons actively occupying that space and their modes of

\footnotetext{
40 Jerome ep. 22.25-6. ${ }_{41}^{4}$ Jerome ep. I30.19.

42 Lovén 2007: 230. $\quad{ }^{43}$ Lovén 2007: 23I.

44 Wallace-Hadrill I996. 45 Hales 2003: I24-7.

${ }_{46}$ Archeology gives little or no evidence for architecturally defined 'women's space' in either Greek or Roman homes. Lisa Nevett's study uses ethnographic evidence to strengthen her case for the fluidity of gendered space in classical Greek homes. See Nevett I994.
} 
interaction with that space. ${ }^{47}$ The atrium or some other relatively large domestic space became a stage for the display and inculcation of feminine virtue through the activity of Demetrias and the other women of the household. Archeological evidence shows that the meaning of particular rooms, rather than inhering in the physical spaces, came into being through their usage and changed over time depending on who was in a room and what he or she was doing. The symbolic import of the atrium or cubiculum could remain relatively neutral or acquire heightened force through the display of activities like prayer, woolworking, the salutatio, alms-giving, or instruction. Although just before the passage above, Jerome has urged Demetrias to leave money matters to Juliana and Proba, he sees Demetrias as a busy overseer in a workshop of virgins who owe their chastity to her industrious example. ${ }^{48}$ These virgins included peers, members of the family's client class, freedwomen, and slaves. They can sell their cloth to aid the poor or turn the cloth over to the two older women in hopes of encouraging them to further charity. Jerome envisions as many 'interior' audience members for Demetrias' domesticity as does Pelagius.

When discussing the public outings that the virgin must make - to church, to martyrs' festivals at tombs, and to the baths if absolutely necessary - Jerome paints a satiric picture of a world so overrun with decadent women, prettified youths, and lustful clerics that a virgin would do better to stay at home even on the feast days of the church and suggests that the city streets are safer than religious gathering places. ${ }^{49}$ This sort of extraordinary retreat from public space would be, in itself, a form of publicity. Public absence from an entirely acceptable occasion for gathering underscored reputation and domesticity rather than simply hiding a woman from view and potential worldly dangers. Again, it is the regulation and presentation of staying in the home, receiving visitors, and going into public space that matters, much more so than the simple facts of going out frequently or not.

\section{Domesticity viewed through the micro-politics of purdah}

The funerary epigrams and statuary have provided a concrete and specific starting point for thinking about Roman women's domesticity and the public advertisement of that domesticity. Two examples from contemporary ethnographies will give a richer insight into the possible subtleties

47 Hendon 2007: I50. ${ }^{48}$ Jerome, ep. I30.I5.

49 Jerome, ep. I30.19. For more on the role of satire in Jerome and Pelagius see Chapter 5. 
of day-to-day creation of domestic reputation. Both concern the concept of 'purdah,' which in South Asian contexts, Muslim and Hindu, refers to the practices of gender segregation and women's seclusion, of varying degrees, within the home. Upper-class Roman women, unlike Greek women, did not practice strict seclusion. Indeed Roman writers considered it a mark of difference between Romans and Hellenes that their women could go abroad, eat with male guests, accompany their husbands to dinner parties, and attend public rituals and entertainments. ${ }^{\circ \circ}$ The reputation of upper-class Roman women, and by extension their entire household, did depend on a perception of domesticity, however, if not seclusion. Let us imagine the Roman woman's domesticity through the particular instances of 'purdah' in the following examples and use them to consider the range of behaviors and performances for which Demetrias, Juliana, and Proba would have been responsible in order to maintain the ordinary reputation of an aristocratic home and the superlative reputation of a publicly pious household, one that Augustine could name 'no small church of Christ.'s

'Purdah,' also transliterated 'parda,' means literally 'curtain' and refers to the practices surrounding sex segregation in Hindu and Muslim communities in South Asia. 'Purdah' separates women from men outside the household and separates men and women within the household, depending on marital and kinship relationships as well as circumstance. Purdah can refer both to the physical segregation of the sexes and to women's veiling that creates this segregation in mixed settings. Generally, in South Asian Muslim communities women maintain purdah according to marital or kinship relationships with a man. Thus, a woman maintains more boundaries with unrelated men, strangers to the family, and fewer with her kin and marital relations. A North Indian traditional Hindu woman, by contrast, maintains the strictest forms of purdah from senior men within her marital family: her father-in-law and her husband's elder brothers. She does not observe purdah on a visit to her natal home. In both Muslim and Hindu contexts purdah tends to be a class marker; the better able a family is to afford seclusion for its women, the more prestigious it is. ${ }^{52}$ These generalizations, of course, hardly cover the complexities of purdah as it is lived across wide geographic, religious, socio-economic, and individual territory. A woman living 'in purdah' might be in seclusion in her father's

so Dunbabin 2003; Babbit I93I.

${ }_{51}$ Augustine. ep. I88.3: "domum enim uestram, non paruam Christi ecclesiam deputamus." CSEL 57.

52 Papanek and Minault I982: 3. 
and then husband's home for the greater part of her life. ${ }^{53}$ Or she might travel both locally and internationally while adjusting her level of veiling to fit many different circumstances.

The two women we will use to think with are, like Demetrias and her elders, persons of unusual religious status. They are both religious experts. Shobhag Kanvar is a Hindu woman who is a ritual storyteller. She knows a repertoire of tales appropriate to religious rituals for women and is acknowledged in her community as an accomplished performer. Amma ${ }^{54}$ is the wife of a Sufi Muslim teacher, which gives her a certain religious status, but is also a popular practitioner of religious healing techniques who has disciples of her own. Both women negotiate their roles as women in purdah. Both must face the challenges of presenting themselves as pious women who are in the unusual position of dealing more frequently with men and the world outside the domestic realm than their lay counterparts, precisely because of their piety.

We turn first to Shobhag Kanvar whom anthropologist Ann Grodzins Gold met in the late 1980s and 1990s. Gold writes about one set of encounters with Shobhag Kanvar and one story in her repertoire that her female audience found particularly funny in her essay, "Purdah is as Purdah's Kept: A Storyteller's Story." ${ }^{55}$

Shobhag Kanvar meets with a group of women to worship the goddess and several other deities, an occasion on which she performs the story of the Brahmin Girl and Ganeshji. ${ }^{56}$ In this tale a young Brahmin daughter-in-law worships the image of Ganeshji daily, but instead of using pure or costly substances, she worships with coals from the cremation grounds and butter from the God's own bellybutton. Any substances associated with deaths or corpses and any bodily fluids are ritually polluting. The God finds this all very funny and places his finger on his nose (trunk) as a joke. The townspeople are distraught by what they see as an inauspicious change in the deity's image and call in ritual specialists who cannot cause the God to put his finger down. The young daughter-in-law asks the king what boon will

53 Jeffery 1979. In Jeffery's study, the women of a community of religious experts who keep the shrine of a Muslim saint, pir, almost never leave their homes and laugh that they cannot give directions to the anthropologist to places in their immediate neighborhood. The religious authority of the men rests, in various ways, on the superlative modesty and decency of their domestic sphere, which is physically attached to the shrine.

${ }_{54}$ 'Amma' is a title of respect, 'mother,' not a proper name. Her husband is referred to throughout as 'Abba,' 'father.'

"Gold I994.

${ }^{56}$ Lord Ganesh, the elephant-headed God. 
be hers if she can convince the statue to return to its original position, and she extracts a promise of great wealth. The story continues:

At Ganeshji's place the Brahmans from Banaras were still sacrificing, but Great Ganeshji didn't take his finger down from his nose. Then the girl said, "Hang up a curtain [parda] in front of Ganeshji, and I will come over there."

She took a short stick and double water pots, and she filled her pots with water and bathed Ganeshji. And she ran to the cremation ground and brought fire, and from Ganeshji's navel she took clarified butter and made an offering.

Behind the curtains she said, "Ganeshji, I have bathed you; I have brought fire from the cremation ground, and I have given you an offering of your own butter, and you have put your finger on your nose. Now take your finger down; if you don't, then I will take this stick and break your icon into little pieces."

Great Ganeshji understood. "Yes, it's true, this girl is telling the truth." Then Ganeshji started laughing, and blooming flowers fell of their own accord, and his hand came down. She removed the curtain, and all the world saw. ${ }^{77}$

Gold tells us that in this story the deity is pleased by the girl's cleverness and audacity. Shobhag Kanvar and her female audience are also amused. Although they are mostly older, no longer in the very junior position of the daughter-in-law, they like the rebellious, tricky girl who uses her seclusion to give cheap, polluting offerings to the God, to form intimacy with the God who is in on the joke, and to raise her status by outdoing the expert priests. The women who form Shobhag Kanvar's audience also live in purdah. Perhaps their women's rituals, secluded from the world of male priestly power, also form intimacy with the God that outdoes that of the authorities? The Brahmin Girl does not reject her low status as a young daughter-in-law or the restrictions of purdah, rather she uses them to her own advantage, and Ganeshji laughs right along with her. God can accept an impure offering or be moved by a threat if he wants to. God, after all, does not have to obey priests if he would rather obey a 'lowly' young daughter-in-law.

Gold continues her essay by discussing the various ways that the storyteller negotiates her own life as a woman living 'in purdah.' Shobhag Kanvar consistently remarks on her life in purdah and the obligations that it entails, such as 'never' leaving her own home and not being able to go to certain places in the village. She is, however, often called on to leave her home to

57 Gold 1994: I66-7. 
perform rituals with other women and to worship Dev Narayanji at his shrine at the edge of the village. Dev Narayanji is a deity to whom she is passionately devoted but who is outside her family's usual set of gods. Men and women from a variety of castes worship Dev Narayanji, and Shobhag Kanvar both invites non-related male co-worshippers into her home for devotions and goes on pilgrimage with them. Gold gives the following account of the storyteller's negotiation between preserving her own purdah and instructing the anthropologist in feminine modesty.

From the early days of our acquaintanceship, Shobhag Kanvar gave me many lessons in the fluidity of the purdah concept, as she kept it. She told me more than once that married women of her caste simply don't leave the courtyard: not to bathe in the pleasant water tank, not to fill water pots at the well. Yet, wishing to instruct me in the art of bathing in the tank (which required deft modesty in changing clothes, which at first I lamentably lacked), she went there with me, saying, "I never go." 58

In the case of the Brahmin Girl of the story, purdah is kept, but not quite for the purposes one might expect. In Shobhag Kanvar's own case purdah is not always strictly observed, but she discusses her observance in general and emphatic terms. She knows well enough the etiquette of bathing in the public tank to teach her American guest, but it is important for her to relay the information that she 'never' goes, that women of her caste 'never' leave their own courtyards. In the tale, the Brahmin Girl literally manipulates the boundaries of purdah by ordering a curtain to be hung, behind which she deals with Ganeshji. Shobhag frequently crosses the usual boundaries of purdah but creates her identity as a woman in purdah through her commentary on her own action, not least in her storytelling. The female space of purdah is not fixed, either in place or conceptually, but grows out of series of actions, statements, and interpretations by the women. These are, of course, set in constant relation to fixed places and material objects, but 'seclusion' is, as archeologists of ancient women suspect, the mutual work of places on people and people on places. 59

Like Shobhag Kanvar, Amma is a ritual specialist. She is a Muslim healer who provides diagnostic services, written amulets, exorcisms, and

58 Gold 1994: 170.

59 "The idea that certain parts of a dwelling area or the social landscape more generally may have strong symbolic associations with gender is not in itself problematic (Low and Lawrence-Zúñiga 2003). However, application of this possibility has generally been informed by an unreflexive structuralism that assumes the existence of binary opposition between male and female space that does not take into account how meaning is created through practice in a dynamic and often spatialized process. Static assumptions about gendered space have also led to simplistic notions of how such space would be used, notions contradicted by studies of spatial associations." Hendon 2007: I50. 
advice to a wide clientele of men and women, Hindu and Muslim, in Hyderabad. She does not observe purdah while engaging in her healing business. The healing space is a part of her home, and Muslim women traditionally do not veil in their homes except in front of non-kin. Her husband keeps a small shop in the same space and the clients become fictive kin of Amma and Abba. Anthropologist Joyce Flueckiger worked with Amma for several years during the I990s. She describes the manipulation of the segregating curtain at a sama, a gathering for the singing of Sufi devotional songs, to which hired singers (qavvals) are invited and at which worshippers may go into trance (wajd).

The physical manipulation of the curtain itself is an evocative image for the negotiation of gendered positioning at the sama. On several occasions when male disciples were hanging the curtain, Amma manipulated how low it hung to the floor so that when she was seated directly behind it, she would be able to lift it or peek under or around it to be able to see what is happening at the sama, rather than just hearing it. Once, as she and the disciples were literally pulling back and forth the curtain, she exclaimed, "What are you doing? Don't you think we women want to see?" Amma herself often sits at the entrance of the curtained area (the curtain does not extend all the way to the wall, leaving a walkway), where she can both see and be seen.

The women do not sit behind the parda until the qavvals arrive; they sit with the men around the dastarkan and participate in the antiphonal recitation of the salamat. Further, during the tea break in the middle of the sama, male disciples come back behind the curtain, serve tea to the women, and often sit to converse with Amma and their female relatives and other female murids. I once asked Amma why they hang the curtain at all when all of the men sitting on the other side (other than the qavvals) are either relatives or disciples, in front of whom neither she nor the other female relatives and/or murids veil. Further, in the healing room she openly sits unveiled to meet both known men and strangers. Amma laughed at my question and rather quizzically affirmed, "Yes, you're right!" But then one of the other women sitting with us explained that it is not right for men to see women in trance/wajd, when their saris might be mussed up and fall off their shoulders; this is why the curtain is hung. ${ }^{60}$

Here we glimpse the push-and-pull of the curtain from both sides of the gender divide. Interestingly, the level of self-consciousness about why the curtain is necessary for the maintenance of purdah is less relevant for the participants than for the anthropologist guest. Amma agrees that one

\footnotetext{
60 Flueckiger 2006: 218-I9. A murid is a disciple, dastarkan is the ritual counting of seeds onto a tablecloth as the group recites the Names of God or other verses.
} 
would not normally segregate from the men who happen to be at the devotional singing; another woman gives her interpretation of the necessity. The general production around setting up the curtain and deciding its boundaries creates the identity of the women as 'women in purdah' more than that segregation itself, especially considering that they do not veil before the men present either before or after the performance. Each push and pull of the physical curtain constitutes a move in the micro-politics of the purdah performance. At stake are both men's and women's conceptions of appropriate segregation and how to achieve that segregation. Also at stake are Amma's self-conception and self-representation as both a modest Muslim woman and a religious leader. For her male disciples, access to a spiritual center is at stake, their own reputations as modest men who respect the boundaries of purdah, and their relationship to the wider realm of Sufi piety in the presence of Amma's husband and the official performers, the musicians.

There is continual communication from one side of the curtain to the other during the course of the sama. Abba, seated right in front of the curtain, is aware when a woman on the other side of the curtain enters trance and hands back a small bottle of scent to apply to her nose, to cool down the trance. When she is moved by a particular line or verse, Amma periodically hands forward monetary offerings to one of the disciples on the other side of the curtain, gesturing for him to take it forward to the qavvals on her behalf. Further, Amma herself often goes into trance at the same time as a heightened moment when ramz occurs in front of the curtain. Her wajd, in particular, impacts the male company seated in front of the curtain; they often shift in their "seats" and attempt to look back to see what is happening. ${ }^{6 r}$

Given that one scholar of purdah claims, "The crucial characteristic of the purdah system is its limitation of interaction between women and males outside certain well-defined categories," ${ }^{62}$ the amount of interaction between the sexes and knowledge exchange across the curtain seems surprising. But as Flueckiger and Gold demonstrate, the crucial characteristic may be more the continuing construction, physical and conceptual, of barriers rather than the policing of inviolable gendered spaces.

These moments of purdah performance give us a chance to review the advice to Demetrias from Jerome and Pelagius. Our texts do not provide access to any of Demetrias' daily moments of domesticity or the gradations of self-awareness, display, and framing she undertook to create

\footnotetext{
${ }^{61}$ Flueckiger 2006: 220-I. Ramz is the twirling dance manifested in trance or ecstatic states.

${ }_{62}$ Papanek 1973: 289 .
} 
a consistent reputation of stay-at-home feminine modesty. The ethnographic specificity of our comparative material, however, charges the vocabulary of Jerome and Pelagius with rich possibility. The 'setting of limits' to formal salutations in the cubiculum, the careful planning of outings and choice of occasions for public self-display, become a vista of opportunities rather than a simple curtailing of mobility and personal freedom. Jerome's vision of Demetrias so busy in prayer, reading, or cloth production that each day seems too short might, at first, appear as a rigorous schedule designed to eliminate any free time for personal thought, action, or decision-making. Demetrias needed to advertise these domestic activities, however, to a critical public audience as well as simply doing them. The amount of actual manual labor a wealthy ascetic woman might have done is debatable; the imperative to represent herself as the sort of woman who stayed at home and wove cloth, however, is not. Although Jerome borrows from an ancient tradition associating feminine chastity and modesty with woolworking, he does not invoke an empty commonplace. As for Amma and Shobhag Kanvar, the Anicii women's opportunities to emphasize domesticity, reinterpret norms, and negotiate the boundaries of home and private space presented themselves as daily challenges, particularly for women who lived in the public eye as both aristocrats and ascetic pioneers. Their shared identity as religious specialists is very important. The exceptional nature of Amma and Shobhag Kanvar's religious commitments lessens the strictures of purdah in some ways, but it makes their observances of purdah more public, more staged for the benefit of their reputations. The Anicii women's domesticity and activities of modesty were reframed by the conversion of their household into an ascetic community ${ }^{63}$ The domestic routine of the ascetic noblewoman could remain very close to that of an ordinary laywoman, but the activities would draw a new audience with new understandings of the import of her domesticity.

\section{Entourage and domestic identity}

The upper-class Roman woman was a member of her household wherever she went, and she could make certain that all saw this by taking a portion of her household with her whenever she went out. Also, she could train the members of her household in such a manner that they would represent her, as mistress, and the whole house on any outing they made.

\footnotetext{
${ }^{63}$ For the nature of household asceticism in the previous generation see Rousseau 2005.
} 
Augustine's letter to Juliana and his other missives to the Anician women impress the reader with his conception of the women as heads of a corporate entity, a household consisting of many members of different social rank who take their moral and theological cues from their mistresses. He outlines his trust in the orthodoxy of the women, his opinion that Pelagius' letter to Demetrias is as heretical as anti-Nicene doctrine, and his assumption of the women's spiritual responsibility for the household in the following passage:

Do not let us be deceived about her [Demetrias'] state of mind on this matter, rather make us more certain by writing back. For we know this very well, that you and your household both are and have been worshippers of the indivisible Trinity. But this is not the only place human error creeps in, that something contrary may be understood of the indivisible Trinity. For there are indeed other ways in which one may err most ruinously, such as this one about which I have written you - and perhaps at greater length than necessary for your faithful and chaste understanding. ${ }^{64}$

Augustine is careful to both praise the orthodoxy and virtue of the women and suggest, obliquely, that the two are linked. A truly 'chaste wisdom' would not consider the teachings of Pelagius to be sound in any way; thus, any woman who accepts his teachings cannot be considered chaste. The associations of womanly unchastity and immodesty with incorrect teaching are well established in the discourses of heresy and orthodoxy by the early fifth century. Heresy, like unchastity, is a communicable disease and the mistresses of households are responsible for the virtue and virtuous thinking of all within their domestic sphere. This, of course, was as true for a male head of household as for women. In Augustine's vision of female asceticism, however, women lived, at home and abroad, in a condition of mutual imitation and surveillance. This entourage existence both protected and created the ascetic household as an inviolable body.

In Augustine's brief note of congratulation to Proba and Juliana on the occasion of Demetrias' dedication as a virgin ( $\mathrm{AD} 4 \mathrm{I} 3-\mathrm{I} 4)$, he glories in the domestic increase the women might expect to follow.

May many female slaves imitate their mistress, and lowly women the highborn, may precariously exsulted ladies imitate her humility with greater

\footnotetext{
${ }^{64}$ Augustine, $e p$. I88.IO: "De hoc ergo eius affectu utrum non fallamur, inde nos fac potius rescribendo certiores. nam illud optime nouimus cum omnibus uestris cultores uos esse et fuisse indiuiduae trinitatis. sed non hinc solum error humanus obrepit, ut aliquid secus sentiatur de indiuidua trinitate. sunt enim et alia, in quibus perniciosissime erratur, sicuti hoc est, unde diutius fortasse, quam satis esset uestrae fideli castaeque prudentiae, in hac epistula locuti sumus." CSEL 57.
} 
exsultation; may virgins, who might wish the status of the Anicii for themselves, choose her sanctity. ${ }^{65}$

Jerome describes just such an influx of imitators ${ }^{66}$ and often refers to the example Demetrias must set for her handmaids of all social ranks. Pelagius compares the virgins who gather around Demetrias to the beasts her forefathers' clients sent previously as gifts for the civic games her family supported.

To you, however, every one of the choice virgins is sent, that you may offer them to God as a most precious tribute, and, by your example, rouse to perpetual chastity. They are in service not to you, but, along with you, in service to God. This glorious vow of yours spread by the common talk is celebrated by all. ${ }^{67}$

Pelagius imagines Demetrias and her entourage in terms of the arena and public spectacle. These are the sort of public benefactions her consular male ancestors made to encourage general goodwill among the people and a lasting name in the community. That civic munificence consisted of the blood of unusual animals and gladiators. This tribute and contest are more desirable and publicly celebrated, despite the 'slave' status of Demetrias and her fellow virgins. Like Augustine and Jerome, Pelagius manages to highlight Demetrias' visible family status while insisting that she shares in a humble piety. He imagines her as the leader of the virgin contestants, whose identity is confirmed and consolidated by her holy entourage. However domestic and homebound Augustine, Jerome and Pelagius encouraged Demetrias to be, they also imagined her as part of group that was most conspicuous in its mobility from one location to another, from the domestic space to the church and back again.

About ten years after Demetrias takes the vow of perpetual virginity and begins to gather a community of ascetic women (some certainly already in residence ${ }^{68}$ ), Augustine writes to a community of virgins in Hippo under

${ }_{65}$ Augustine, ep. I50: "imitentur eam multae famulae dominam ignobiles nobilem, fragiliter excelsae excelsius humilem; virgines, quae sibi optant Aniciorum claritatem, eligant sanctitatem.” CSEL 44.

66 "As if from a fecund root, many virgins sprouted all at once, and the example of the patroness and mistress was followed by the crowd of clients and slaves." Jerome, ep. 130.6: "quasi ex radice fecunda, multae simul virgines pullularunt, exemplumque patronae et dominae secuta est clientum turba atque famularum." CSEL 56.

${ }^{67}$ Pelagius, Demetr. I4.2: "Ad te vero electae quaeque virgines mittuntur: quas tu pretiosissimum munus offeras Deo, tuoque exemplo ad perpetuam provoces castitatem: non tibi, sed tecum Deo, servituras. Haec professionis tuae gloria rumore celebri vulgata est per cunctos.” PL 29A-29B.

${ }^{68}$ Augustine, Vid. I, 29; ep. I30.30-I. Both the treatise on widowhood and the letter on prayer assume that the household included a number of consecrated widows and virgins before Demetrias converted to the ascetic life. 
his supervision. The occasion for the letter is a dispute concerning the leadership of the community and the priest who acts as spiritual advisor to the women. The letter was attached, possibly during Augustine's lifetime, ${ }^{69}$ to a feminine version of his rule for monks, which includes instructions on eating, prayer, reading, authority, clothing, and property management. It ends with an admonition to read the letter aloud in the community on a regular basis so that nothing may be forgotten and all the instruction taken to heart or used as a mirror for correcting the faults of the community. Augustine writes on the subject of outings and emphasizes that the monastic must never appear in public without an entourage of companions.

When you go out, walk together, when you have arrived at the place you are going, stand together. In your gait, your standing, your dress, in all of your movements, do nothing which may attract any lust, but rather that which befits your holiness. ${ }^{70}$

He goes on to describe the illicit glances between sexes that the monastic must avoid, and he reminds them that, while their sisters may not see them, God, who sees all, surely is observing those glances that indicate an impure heart. Another long passage follows immediately, in which Augustine gives detailed instruction for the chastisement of monks or virgins who are observed in such eye-flirting. The virgin is here both spectator and spectacle. She is responsible for her own public behavior, which reflects on both herself and her companions, which affects both her own state of virtue and the virtue of men she may encounter. She also observes the conduct of her companions and encourages more virtuous behavior in them through her own example and through careful interventions, private then public. The group of virgins acts in concert in the public sphere and acts as an internal audience at all times for all virgins in the household. Each virgin's display of modesty increases or decreases household reputation. A woman's modesty is under constant scrutiny but is also a source

69 The letter and rule were copied as one document throughout the Middle Ages. Until Luc Verheijen's 1967 study of the manuscript tradition, scholars assumed that the feminine version of the rule was the original and that it had been composed for the use of the community in letter 2II. Verheijen proved to the satisfaction of most scholars that the masculine version of the rule was the original and elements specific to women were later additions. However, linguistic resonance with De Sancta Virginitate suggests that the additions were made by someone within Augustine's circle, if not Augustine himself. For more on the dating of the feminine rule see Verheijen 1967; Lawless 1987.

${ }^{70}$ Augustine, ep. 2II.IO: "quando proceditis, simul ambulate: cum ueneritis, quo itis, simul state. in incessu, in statu, in habitu, in omnibus motibus uestris nihil fiat, quod inliciat cuiusquam libidinem, sed quod uestram deceat sanctitatem." CSEL 57. 
for imitation by all around her. Augustine's advice to monastics indicates, of course, that this was true for the male ascetic as well as the female. Although pudicitia was the feminine virtue par excellence, Roman men, especially young free males, also had reputations for sexual restraint, and sexual inviolability, to maintain. ${ }^{71}$

Demetrias, as a head of household, was even more intensely mirrored by and affected by her entourage than an ascetic in a more formal monastic establishment might be. Jerome explicitly warns Demetrias that her choice of companions for public outings will affect her reputation.

Choose dignified women as companions, especially widows and virgins, of esteemed behavior, measured speech, and holy modesty [verecundia]. Avoid the wantonness of those girls who adorn their heads, let their locks fall on their foreheads, improve their skin, use make-up, ${ }^{72}$ and wear tight sleeves, clothing without wrinkles and curled slippers, so that under the more acceptable title of 'virgin' they are lost at higher cost. For the character and devotion of the mistress is judged by the character of her many slaves and companions..$^{73}$

The speech and dress of Demetrias' companions will have a direct bearing on her public reputation. Although Jerome imagines many women, both her servants and others in her circle, imitating Demetrias' form of life, he fears that she will be overcome by immodesty, or acquire an immodest reputation, if she goes abroad with women who visually and audibly communicate markers of unchastity. The public performance of an ideally domestic self requires a manner of leaving home that includes the choice of a supporting cast that will increase the ascetic mistress's holy reputation. At home by setting an industrious example to ascetic handmaids, abroad by traveling with handpicked companions, the ascetic noblewoman creates her domestic identity as part of a corporate identity of mutual surveillance and imitation.

\section{Conclusions}

Domesticity was an enterprise that required the active and creative work of women, in particular these women who lived in the public eye, as both

${ }_{71}$ Williams 20I0.

72 Following the variant reading pigmentis for lomentis.

73 Jerome, ep. I30.I8: "graues feminae - et maxime uiduae, ac uirgines - tibi comites eligantur, quarum probata est conuersatio, sermo moderatus, sancta uerecundia. fuge lasciuiam puellarum, quae ornant capita, crines a fronte demittunt, cutem poliunt, utuntur lomentis, adstrictas habent manicas, uestimenta sine ruga, soccosque crispantes, ut sub nomini uirginali, uendibilius pereant. mores enim et studia dominarum, plerumque ex ancillarum et comitum moribus iudicantur." CSEL 56. The satiric aspects of this passage and their implications will be discussed in Chapter 5. 
aristocrats and ascetic exempla. The funerary evidence shows the paradox of Roman domesticity: it only had weight as part of the family reputation for virtue if it were made public, brought outside the home and the private chamber to the roadside display of the family tomb. The epitaphs and statuary allowed a glimpse into the Roman world of gender, material artifacts, and space, where artifacts and space simultaneously engendered subjects and took on gendered meanings through their use by men and women.

Holding the advertisement of domesticity through funerary evidence in mind, we returned to Pelagius' and Jerome's letters of advice to Demetrias. We noted the complex relationships between domesticity and publicity both in and outside the home. Brief descriptions of 'staying in' and 'going out' revealed the agency of the virgin in creating domestic space, a domestic persona, and a superlatively domestic reputation in her religious household. Ethnographic data from South Asia enriched our understandings of how these spaces and reputations might be created in the micro-politics of day-to-day gender performance. Finally, we considered the expansion of the domestic subject through her identification with an entourage for whom she was morally responsible. In each of these cases we see that domesticity was not so much a matter of a woman remaining in a particular space but of a woman creating a self and a persona who interacted with spaces in such a way as to convince an audience (both within and outside the home) of her domestic virtue. This kind of work has often been described as 're-inscribing norms.' However, the aspects of performance involved in such a re-inscription belie an understanding of this activity as 'automatic' or 'habitual.' Living into the norm of Roman feminine domesticity was a challenge for the urban matron who valued her family reputation; living into the exceptional domesticity of the Christian virgin, who was often praised as surpassing Roman matrons in every way, was a public spectacle. 